\title{
The Development of on Job Training Assessment Constructs and Elements for Construction Technology Students in Malaysian Vocational College
}

\author{
Nurhafizah Abdul Musid ${ }^{1}$, Haryanti Mohd Affandi ${ }^{2 *}$, Siti Hamidah Husain ${ }^{3}$, \\ Mohd Firdaus Mustaffa Kamal ${ }^{4}$, Nor Haslinda Abas ${ }^{5}$
}

${ }^{1}$ Educational Planning and Research Division, Ministry of Education, Putrajaya, 62604, MALAYSIA

${ }^{2 *}$ Centre for Engineering and Built Environment Education Research, Faculty of Engineering and Built Environment, The National University of Malaysia, Bangi, 43600, MALAYSIA

${ }^{3}$ Faculty of Engineering and Built Environment, The National University of Malaysia, Bangi, 43600, MALAYSIA

${ }^{4}$ Faculty of Technical and Vocational, Sultan Idris Education University, Tanjung Malim, 35900, MALAYSIA

${ }^{5}$ Faculty of Civil and Environmental Engineering, Universiti Tun Hussein Onn Malaysia, Batu Pahat, 86400, MALAYSIA

DOI: https://doi.org/10.30880/jtet.2019.11.01.004

Received $6^{\text {th }}$ November 2019; Accepted 14 November 2019; Available online $31^{\text {st }}$ March 2019

\begin{abstract}
On Job Training (OJT) (organisation) assessment rubric is widely considered instrumental in assessing Diploma in Construction Technology students with required competencies to function effectively in the work environment. OJT remains predominantly process-focused with little attention to the criteria in OJT (organisation) assessment rubric. The aim of this study is to develop constructs and elements for OJT (organisation) assessment rubric. The research design for this study is a survey that was carried out qualitatively through document analysis to identify the constructs and elements in the OJT (organisation) assessment rubric. From meta data analysis, 110 elements are identified to be the constructs and elements in OJT (organisation) assessment rubric. After the expert validation process using questionnaire form as an instrument, only 75 elements are valid to be included in the OJT (organisation) assessment rubric while 35 elements discarded. The majority of experts agreed that four elements are suitable to be constructs of soft skills, 5 items are suitable to be constructs of technical skills while remaining 66 elements divided into technical skills and soft skills. Based on the 66 elements, 45 elements are technical skills and 21 elements in soft skills. Therefore, it is suggested to conduct a pilot study for the reliability of constructs and elements of developed OJT (organisation) assessment rubric of Diploma in Construction Technology.
\end{abstract}

Keywords: On Job Training, assessment rubric, Diploma in Construction Technology, constructs, elements

\section{Introduction}

According to Malaysia Education Blueprint 2015 - 2025 (Higher Education), producing quality technical and vocational education and training (TVET) graduates is one of the shifts to achieve the system and student aspirations (Ministry of Education, 2015). Therefore, through its vocational colleges as one of the premier higher education TVET provider, it develops skilled talent to meet the growing and changing demands of industry and promotes individual opportunities for career development (Ministry of Education, 2015). One of the key initiatives to achieve these outcomes include industry 
involvement and partnerships (Ministry of Education, 2015). Industrial training or also known as On Job Training (OJT) must be performed by students in every programme in Vocational College (Ministry of Education, 2014).

Diploma in Construction Technology is one of the programmes offered by Malaysian Vocational College (VC). Students need to complete their study in eight semesters and perform On Job Training (OJT) as a prerequisite to gain Malaysian Vocational Diploma (Ministry of Education, 2014). During OJT, students have to go to any government agencies or private sector approved by VC for compulsory training at a real workplace (Ministry of Education, 2016). Students need to pass OJT in order to be graduates of Malaysian Vocational Diploma (Ministry of Education, 2014). Therefore, an assessment process of OJT is vital in determining students' performance.

The total marks for OJT assessment are $100 \%$ which $40 \%$ of the total marks will be given by the organisation while $60 \%$ of the total marks will be given by the lecturers from the VC (Ministry of Education, 2016). The quality of industrial attachment supervision and assessment depends on how the lecturers and workplace supervisors and assessors interpret and apply the contents of the assessment form itself but assessors' incompetency is a potential threat to quality assurance management systems (Chinyemba et al., 2012). Therefore, to make reliable assessments, assessors must be competent enough in terms of their own assessment competencies, have the relevant technical competencies, or have access to a subject matter expert who can advise the assessor on the relevant vocational competencies at least to the level being assessed (Chinyemba et al., 2012).

In training report for the white card for Australia's construction industry, there are some issues in training assessment being highlighted (Australian Skills Quality Authority, 2013):

i. Do not adequately assess the communication and comprehension skills required by the training package.

ii. $\quad$ Poor quality in training delivery and assessment.

iii. Poor reliability of assessment including in particular, assessment of the required level of competence in communication skills.

iv. Training and assessment strategy not consistent with practice; no assessment strategy for assessing communication skills.

In organising an assessment, there are a variety of tools such as checklists, rating scales and rubrics that state specific criteria that allow teachers and students to make judgments about developing competence (Manitoba Education, Citizenship \& Youth, 2004). OJT assessment involves the usage of rubrics (Ministry of Education, 2016). However, there are certain issues arose the usage of rubrics (De Luca \& Bolden, 2014); Firstly, it is difficult to articulate criteria that accurately describe the nuances of student performance. Secondly, the criteria provide students with little guidance on how to improve their performance through formative assessment. Thirdly, rubric criteria often focus solely on technical skills because these are more easily observed and measured, and because these skills are emphasised in standards-based curricula.

The effective assessment requires specification criteria and procedure that is fair to all (Grondlund, 1998). Selection of criteria and drafting the descriptors is highly subjective and contextual (Reddy, 2011). High-quality criteria specifically describe performance qualities by articulate distinguishable levels of performance accurately and fully identifying what is going on (De Luca \& Bolden, 2014). These bring in the much-needed clarity in understanding the requirements of performance especially in areas which are difficult to define, such as critical thinking, problem-solving, team skill (Reddy, 2011). These also permit criterion-referenced discrimination of performances and enable monitoring of students learning against each criterion (Reddy, 2011). The criteria thereby provide the students with opportunities to reflect on both the content of their performance as well as the process of learning (Parke, 2001).

In designing descriptive rubric criteria, the concept of enabling constraints is useful in addressing and encouraging both technical and expressive performance qualities (De Luca \& Bolden, 2014). Selection of criteria and drafting of descriptors depend on the programme and course, quality of students, instructor's experience and expertise (Reddy, 2011). Criteria for too much choice may be overwhelming for students, not providing sufficient structure to help shape their learning while criteria that are too prescriptive limit creative possibilities and restrict artistic learning (De Luca \& Bolden, 2014). In order to get good quality results and accurate assessment of evaluation, there is a need to develop analytical standard reference criteria for teachers and student as well (Ab Rahman et al., 2014). Therefore, this paper aims to develop constructs and elements for OJT (Organisation) assessment rubric for Diploma in Construction Technology as the quality of criteria that determine the effectiveness of the rubric for assessing and promoting student learning (De Luca \& Bolden, 2014). This study has two objectives which are to identify constructs and elements for OJT (Organisation) assessment rubric based on document analysis and to validate the constructs and elements by using expert validation.

\section{Methodology}

The research design chosen in this study is a survey that is analysed qualitatively through document analysis and expert validity. The document was analysed using meta data method. The document used in this study are Course Learning Outcomes (CLO) of Diploma in Construction Technology (Department of Technical Education and Vocational, 2017), CLO of OJT (Department of Technical Education \& Vocational, 2017), National Occupational Skills Standard (NOSS) for Level 3 Construction Site Supervisory and Management from Department of Skills Development and Construction 
Industry Development Board (CIDB) (Department of Skills Development, 2016) and Vocational College Standard Curriculum (Department of Technical Education and Vocational, 2017).

Document analysis focuses on how the different elements of the text combine to consolidate meanings alongside the assumptions in the text (Rapley, 2007). Through meta data analysis, constructs and number of elements in each document are listed out. By doing this, it will document the specific discourses it draws on alongside the specific identities or subject positions that are produced sustained or negotiated (Rapley, 2007).

After identifying items for constructs and elements from meta data analysis, this finding is validated by the experts through expert review. According to Burns (2000), referring to the expert panel are the most common way in getting evidence content validity of an instrument. When using expert review, item quality and content relevance were determined based on reviewers' matching of individual items with either perfectionism or paternalism and their judgment of whether the item related overall to expert autonomy (Green \& Frantom, 2002). The findings of the document analysis validated by three experts. Table 1 describes the background of the experts in validating the document analysis.

Decisions to retain items to be constructs or elements for OJT assessment rubric (Organisation) were based on the following criteria (Green \& Frantom, 2002); First, items received at least three votes for either paternalism or perfectionism from the experts. Second, item received at least three votes for being related to expert autonomy.

Table 1 - Experts Description for Validating Document Analysis.

\begin{tabular}{ll}
\hline No & Experts Description \\
\hline Expert 1 & The expert is an academician for 28 years. He is a lecturer of quantity surveying \\
course in a Malaysia's public university. He is also an assessor for Malaysian \\
Qualifications Agency (MQA) and a member of Association of Construction \\
Project Managers Malaysia (ACPM). He is actively involved in projects with \\
Construction Industry Development Board (CIDB). \\
The expert is an academician for 28 years. He is a lecturer of quantity surveying \\
course in a Malaysia's public university. He is also an assessor for Malaysian \\
Qualifications Agency (MQA) and a member of Association of Construction \\
Project Managers Malaysia (ACPM). He is actively involved in projects with \\
Construction Industry Development Board (CIDB). \\
The expert is an academician for 28 years. He is a lecturer of quantity surveying \\
course in a Malaysia's public university. He is also an assessor for Malaysian \\
Qualifications Agency (MQA) and a member of Association of Construction \\
Project Managers Malaysia (ACPM). He is actively involved in projects with \\
Construction Industry Development Board (CIDB).
\end{tabular}

Expert 2 The expert is an academician. He is a lecturer of building surveying in a Malaysia's public university. He is also a Registered and Professional Building Surveyor in Malaysia, Chartered Building Engineer (UK) and Committee Member of Malaysian Association of Registered Building Surveyors (MyRBS). Apart from that, he is a Fellow Member of The Chartered Association of Building Engineers (CABE), United Kingdom and a Malaysian Green Building Index (GBI) Certified Facilitator.

Expert 3 The expert is a consultant in (CIDB the expert is a consultant in training for site supervisor. He has experience in construction industry and a trainer at Construction Industry Development Board (CIDB).

Expert 4 The expert is an academician. Since 1989, he has been a lecturer of Construction Management in a public university. He is a Corporate Member of Chartered Institute of Building (CIOB) UK. He is also a Registered Building Surveyor with MyRBS and a Fellow in The Royal Institution of Surveyors Malaysia. Currently, he is the Vice President of The Association of Construction Project Managers Malaysia and holds a Certified Construction Project Managers (CCPM) Certificate from CIDB. He is also an assessor for Malaysian Qualifications Agency (MQA) in the area of construction and project management. He is actively involved in many activities and initiatives with Construction Industry Development Board (CIDB). 


\section{Result and Discussion}

\subsection{Document Analysis}

Based on the meta data analysis of those four documents, there are a few constructs and elements identified in each document. Two of the documents are CLO of OJT and CLO of Diploma in Construction Technology. CLO is carefully established from the Programme Outcome for each programme that determines the objectives of the course and what are expected out of each student in a learning institution which commonly derived from Bloom's Taxonomy (Aziz, 2011). There are three domains in Bloom Taxonomy which is cognitive domain, psychomotor domain, and affective domain (IACBE, 2014). Level of expertise in cognitive domain are creating, evaluating, analysing, applying, understanding and remembering (IACBE, 2014). While, level of expertise in psychomotor domain are perception, set, guided response, mechanism, complex overt response, adaptation, and organisation (IACBE, 2014). Next, level of expertise in affective domain are receiving, responding, valuing, organisation and characterisation by a value or value complex (IACBE, 2014).

Meanwhile, NOSS is a defined as a specification of competencies expected of a skill worker who is gainfully employed in Malaysia for an occupational area, level and pathway to achieve the competencies (Department of Skills Development, 2016). There are five level of competency in NOSS which are Level 1, Level 2, Level 3, Level 4, and Level 5 (Department of Skills Development, 2016). This study is using NOSS Level 3 as the aim of Diploma of Construction Technology is to produce a site supervisor (Department of Technical Education and Vocational, 2017). The definition of Level 3 NOSS is competent in performing a broad range of varied work activities, performed in a variety of context, most of which are complex and non-routine. There is considerable responsibility and autonomy and control or guidance of others is often required (Department of Technical Education and Vocational, 2017).

Vocational College Standard Curriculum is a technical and vocational education and training curriculum that complies to NOSS and Malaysian Qualifications Agency (MQA) (Buletin Anjakan, 2015). Students have to attend PreDiploma Programme for two years and if they eligible for qualification, they may continue their studies to Diploma Programme in Vocational College for another two years (Buletin Anjakan, 2015).

Table 2 below shows constructs and elements in each document in detail. In total, there are 110 elements were listed out to be constructs and elements of OJT (Organisation) assessment rubric for Diploma in Construction Technology.

Table 2. Meta data analysis specification table

\begin{tabular}{|c|c|c|}
\hline Document & Construct & Element \\
\hline $\begin{array}{l}\text { Course } \\
\text { Learning } \\
\text { Outcomes } \\
\text { (CLO) of On } \\
\text { Job Training }\end{array}$ & $\begin{array}{l}\text { Cognitive Domain } \\
\text { Psychomotor } \\
\text { Domain } \\
\text { Affective Domain }\end{array}$ & $\begin{array}{l}\text { Apply Problem Solving Skills, Critical Thinking \& Scientific Approach } \\
\text { Apply knowledge and relevant skills in the workplace }\end{array}$ \\
\hline $\begin{array}{l}\text { Course } \\
\text { Learning } \\
\text { Outcomes } \\
\text { (CLO) of } \\
\text { Diploma in } \\
\text { Construction } \\
\text { Technology }\end{array}$ & Cognitive Domain & $\begin{array}{l}\text { Prepare taking off for various types of building trades } \\
\text { Identify suitable machineries and equipment for mobilisation on site } \\
\text { Prepare materials for roof structures and covering based on working drawings } \\
\text { Erect masonry retaining walls based on drawing plan } \\
\text { Determine the needs and equipment for demolition works } \\
\text { Prepare progress claims based on construction work variations } \\
\text { Produce project proposal based on given situation } \\
\text { Apply site investigation standard method and procedures based on civil and } \\
\text { structural work programme } \\
\text { Identify civil engineering works monitoring assessment based on Master Work } \\
\text { Programme } \\
\text { Discuss the structural works monitoring in progress report } \\
\text { Determine specifications based on the nature and scope of construction works } \\
\text { Arrange for acquisition of construction materials according to proposed project } \\
\text { Construct the community project as a continuation of Community Project I }\end{array}$ \\
\hline & $\begin{array}{l}\text { Psychomotor } \\
\text { Domain }\end{array}$ & $\begin{array}{l}\text { Practice estimation and costing works for construction resources } \\
\text { Prepare clearance for designated construction site with hoarding board and } \\
\text { appropriate machineries } \\
\text { Fix roof structures including covering and insulation materials using proper } \\
\text { procedures } \\
\text { Fix decorative masonry walls using ashlar type based on working drawing }\end{array}$ \\
\hline
\end{tabular}




\begin{tabular}{ll}
\hline Construct & Element \\
\hline Perform extension and renovation works based on given situation \\
Practice project scheduling using suitable software \\
Practice cost estimation and reproduce detail drawing based on given situation \\
Prepare contract document to obtain authority approval \\
Establish civil engineering works monitoring based on Master Work \\
Programme \\
Reproduce technical documentation on structural works \\
Prepare specification document to continually improve quality planning in \\
construction works \\
Build community project based on approved plan \\
Produce civil and structural progress report for approval submissions \\
Practice the skills of personnel management according to rules and regulations \\
at construction site \\
Conduct activities to finalise the project contract \\
Build the approved Community Project I
\end{tabular}

Affective Domain Assist in preparing Gantt chart for construction work scheduling Communicate in team to prepare temporary facilities based on site plan Practice structures and ceiling fixing according to proper procedures Assist in erecting gabion masonry walls based on designated shapes Cooperate in planning for extension and renovation works based on given situation

Organise site meeting for construction work activities based on master work schedule

Explain the completed community project proposal through presentation Organise activities prior to construction Manage civil engineering works based on Master Work Programme Visit pre-stressed, precast and load-bearing wall construction work sites Practice quality policies and procedures in construction works Write progress report for the undergoing project Assist in the administration of construction project management

Assist in personnel management at construction site

Assist in leading the preparation of tender document and tender notice based on contract and procurement procedures

Prepare for constructed project hand-over

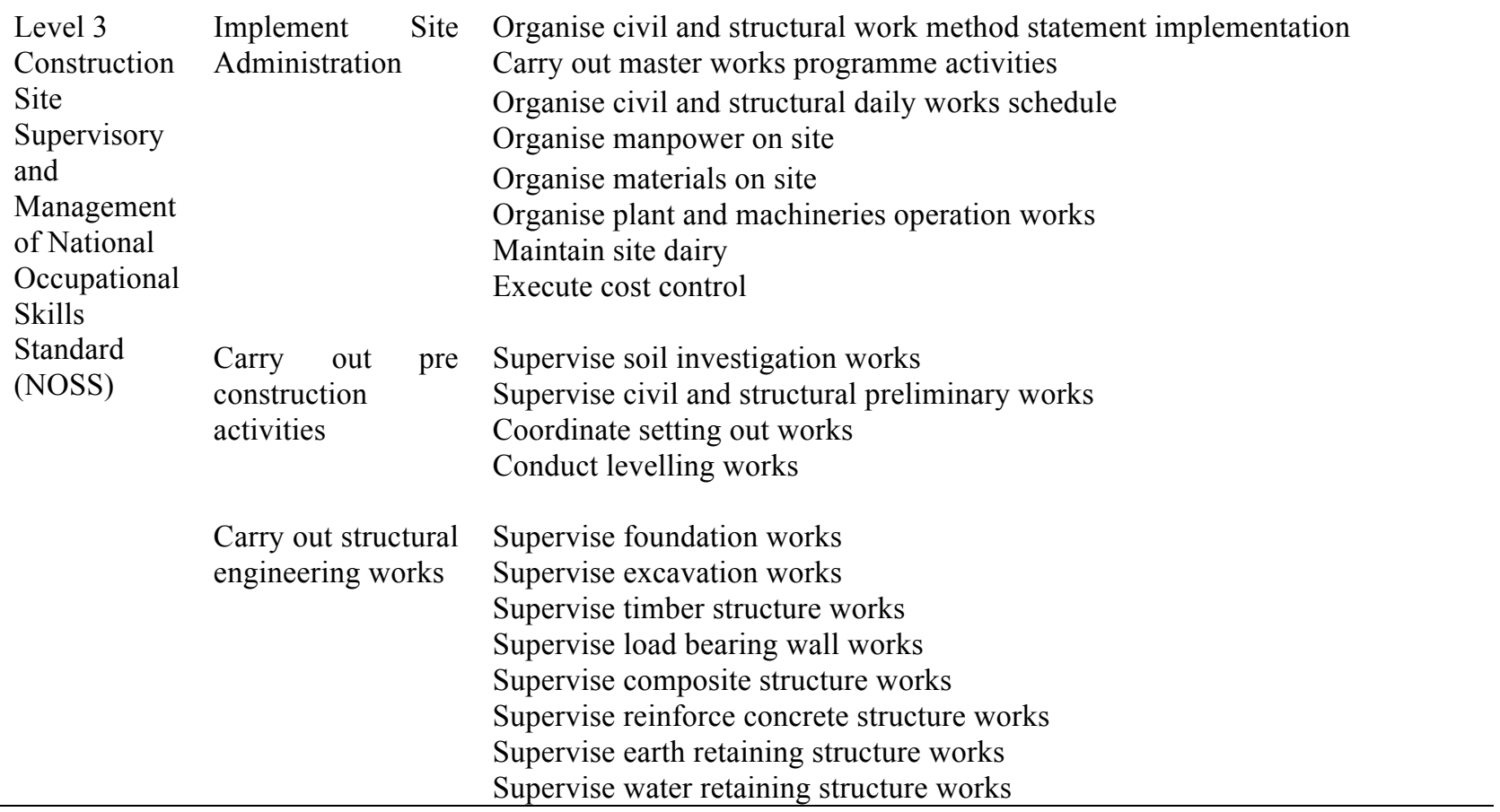




\begin{tabular}{|c|c|c|}
\hline & & Construct \\
\hline & & $\begin{array}{l}\text { Supervise steel structure works } \\
\text { Supervise temporary structure works }\end{array}$ \\
\hline & $\begin{array}{l}\text { Carry out civil } \\
\text { engineering works }\end{array}$ & $\begin{array}{l}\text { Supervise river protection works } \\
\text { Supervise reservoir and water tank construction works } \\
\text { Supervise waste water engineering works } \\
\text { Supervise water supply and reticulation works } \\
\text { Supervise drainage works } \\
\text { Supervise traffic control } \\
\text { Supervise road works } \\
\text { Supervise road furniture installation } \\
\text { Supervise earth works } \\
\text { Supervise remedial works }\end{array}$ \\
\hline & $\begin{array}{l}\text { Perform civil and } \\
\text { structural } \\
\text { construction } \\
\text { management }\end{array}$ & $\begin{array}{l}\text { Compile civil and structural works progress record } \\
\text { Compile construction defect list } \\
\text { Execute safety, health and environmental requirements } \\
\text { Perform quality control } \\
\text { Coordinate laboratory testing works } \\
\text { Supervise field testing works } \\
\text { Participate in technical meetings } \\
\text { Supervise testing and commissioning works } \\
\text { Liaise with other site personnel } \\
\text { Coordinate with authorities } \\
\text { Carry out site work measurement }\end{array}$ \\
\hline & $\begin{array}{l}\text { Perform } \\
\text { supervisory } \\
\text { administrative } \\
\text { functions }\end{array}$ & $\begin{array}{l}\text { Supervise personnel performance } \\
\text { Attend to personal welfare } \\
\text { Supervise personnel discipline }\end{array}$ \\
\hline $\begin{array}{l}\text { Vocational } \\
\text { College } \\
\text { Standard } \\
\text { Curriculum }\end{array}$ & Soft Skills & $\begin{array}{l}\text { Communication Skills } \\
\text { Critical thinking and problem-solving skill } \\
\text { Teamwork skill } \\
\text { Lifelong learning and Information Management } \\
\text { Entrepreneurship skill } \\
\text { Ethics and professional morals } \\
\text { Leadership skill }\end{array}$ \\
\hline
\end{tabular}

Course Learning Outcome (CLO) is a document that provides information regarding learning outcome for each subject taught at Vocational College. For on Job Training, there are three types of the domain involved which are a cognitive domain, psychomotor domain, and affective domain. One element is provided for each domain. In total, there are three elements that are suitable to be the elements in the assessment rubric.

For Diploma in Construction Technology, there are 16 subjects under the vocational module. For each subject, there are three CLOs as each of the CLOs represents cognitive domain, psychomotor domain, and affective domain. In total, there are 48 elements according to CLO of Diploma in Construction Technology. Students perform On Job Training after they completed Semester 8 which means they have learned these 16 subjects. Therefore, to assess students' competency during On Job Training, these 48 CLO should be the elements in the assessment rubric. It is because these $48 \mathrm{CLO}$ are more specific in detailing their tasks.

Level 3 Construction Site Supervisory and Management in NOSS is selected because it provides duty and task for a site supervisor who is parallel to the aim of Malaysian Vocational College Diploma in Construction Technology which is to produce a site supervisor. According to Level 3 Construction Site Supervisory and Management in NOSS, there is six duties as a site supervisor which is implemented site administration, carry out pre-construction activities, carry out structural engineering works, carry out civil engineering works, perform civil and structural construction management and perform supervisory, administrative functions. There are eight tasks in implement site administration duty, four tasks in carrying out pre-construction activities, 10 tasks in carrying out structural engineering works, 10 tasks in carrying out civil engineering works, 11 tasks in performing civil and structural construction management and three tasks in performing supervisory, administrative functions. In total, there are 46 tasks as a site supervisor according to Level 3 
Construction Site Supervisory and Management in NOSS. Therefore, these 46 tasks should be the elements while the six duties should be the constructs in the assessment rubric.

Based on Vocational College Standard Curriculum, there are seven elements of soft skills. The elements are communication skill, critical thinking, and problem-solving skill, teamwork skill, lifelong learning and information management, entrepreneurship skill, ethics and professional morals and leadership skill. These seven elements of soft skills should be the constructs in the assessment rubric. It is to ensure that the students produced by the VC possess soft skills elements that are stated in Vocational College Standard Curriculum.

\subsection{Expert Validation}

From the document analysis, there are 110 elements considered to be elements in OJT (Organisation) assessment rubric. The result from document analysis is then referred to experts. According to experts, only 66 elements are accepted to be elements in OJT (organisation) assessment rubric, five elements will be constructs of technical skills and four elements will be constructs of soft skills. Experts have agreed to divide the 66 elements into two constructs which are technical skills and soft skills.

\subsubsection{Technical Skills}

Technical skills refer to a person's ability to master and perform a task or job that involves techniques and methods have been set according to a particular field (Makhtar, 2015). For technical skills, there are six duties under NOSS Level 3 sub-sector construction site supervisor which are implement site administration, carry out pre-construction activities, carry out structural engineering works, carry out civil engineering works, perform civil and structural construction management and perform supervisory, administrative functions (Department of Skills Development, 2016). For implement site administration, there are no changes of elements according to the experts in construction. If the project is well planned from the beginning, this will help in avoiding many problems and confusion later (Najmi, 2011).

For carry out pre-construction activities, the number of elements has increased from four to five because one element under the psychomotor domain of Course Learning Outcomes of Diploma in Construction Technology is suitable to be included in that duty. The task is to supervise site clearance for designated construction site with hoarding board and appropriate machinery (MOE, 2016). The result from the expert validation shows that this task needs to be done after supervising soil investigation works and before conduct setting out works. Ground investigation is carried out to obtain information about the nature and condition of the ground (Wood \& Ashton, 2007). Ground investigation affects the safety of both site operations and of the completed works (Clayton \& Uff, 1986).

Next, for carrying out structural engineering works, there are 14 elements which two elements from the psychomotor domain and one element from the affective domain of Course Learning Outcome of Diploma in Construction Technology enrolled in that specific duty. The three elements are supervised roof structures including covering and insulation materials using proper procedures, supervise decorative masonry walls using ashlar type based on working drawing, and supervise ceiling work according to proper procedures. Another element enrolled in this construct is ensure reproduce of technical documentation on structural work as built drawing. According to result from the expert validation, this is because of these four elements suitable to be in structural engineering works. Structural engineering works relates to the design of buildings (The Institution of Professional Engineers New Zealand Incorporated, 2009).

Then, for carrying out civil engineering works sub skill, one element discarded from the assessment rubric. The element is supervised remedial works. The result from the expert validation shows this element is already assessed through other elements in the carry out civil engineering works sub skill. In modern usage, civil engineering is a broad field of engineering that deals with planning, construction, and maintenance of fixed structures, or public works, as they are related to earth, water, or civilisation and their processes (EngineeringCivil.org, 2016).

Other than that, one element also included in perform civil and structural construction management sub skill. The element is performed extension and renovation work based on given situation. According to the experts, this job scope is suitable to be in civil and structural construction management. While three elements in this sub skill are put under soft skills. One of the elements participates in technical meetings which will be in ethics and professional morals sub skill. Two of the experts said, "If a site supervisor possesses good ethics, the person should be responsible for participating technical meetings as part of the job scope as a site supervisor." While liaise with other site personnel and coordinate with authorities' elements should be in communication skill. This is because ability in negotiating and reach an agreement is the fifth level in communication skill (Ministry of Higher Education, 2006).

Meanwhile, for perform supervisory administrative functions sub skill, all three elements will be put under leadership skill in soft skills. The elements are supervised personnel performance, attend to personal welfare, and supervise personnel discipline. This is because ability in supervising team member is the fourth level in leadership skill (Ministry of Higher Education, 2006).

In total, there are 45 items that should be the technical skills elements for On Job Training (Organisation) assessment rubric for Diploma of Construction Technology. Eight elements should be in implement site administration, five elements in carrying out pre-construction activities, 14 elements in carrying out structural engineering works, nine elements in carrying out civil engineering works and nine elements in performing civil and structural construction management. 


\subsubsection{Soft Skills}

According to Vocational College Standard Curriculum, there are seven soft skills that should be acquired by the VC students which are communication skill, critical thinking and problem-solving skill, teamwork skill, lifelong learning and information management, entrepreneurship skill, ethics and professional morals, and leadership skills (Department of Technical Education and Vocational, 2017). After expert validation process, only four soft skills are relevant to be the constructs for OJT (Organisation) assessment rubric. The soft skills are communication skill, critical thinking and problem-solving skill, ethics and professional morals, and leadership skills.

There are 21 items identified to be the elements in these four soft skills. For communication skills, there are six elements. Four elements from CLO of Diploma in Construction Technology which are discuss the structural works monitoring in progress report, communicate in team to prepare temporary facilities based on site plan, produce short term project scheduling (Gantt Chart) using suitable software, and determine the needs of materials, machineries, equipment (construction source) based on developed work scheduling. While the remaining two elements from NOSS Level 3 subsector construction site supervisor. The elements are liaising with other site personnel and coordinate with authorities. These six elements are suitable to be in communication skills because the first level in communication skill is the ability to communicate ideas clearly, effectively and with confidence, verbally and in writing (Ministry of Higher Education, 2006). Besides, ability in using technology for presentation is also another level in communication skill (Ministry of Higher Education, 2006).

Next, for the second soft skills which are critical thinking and problem-solving skill, there are five items identified to be the elements in the OJT (Organisation) assessment rubric. All these five elements from CLO of Diploma in Construction Technology. The elements are used Gantt Chart in executing construction work, assist in arranging and organising site meeting for construction work activities based on master work schedule, arrange and organise activities prior to construction, perform taking off for various types of building trades and estimate cost for construction resources. These five elements should be in critical thinking and problem-solving skill because ability in finding ideas and finding alternative solutions is the third level in this soft skill while the ability to think beyond bounds is the fourth level in this soft skill (Ministry of Higher Education, 2006).

Then, for the third soft skills, there are five items should be the elements of ethics and professional morals. Three elements come from CLO of Diploma in Construction Technology. The elements are monitor civil and structural works progress in accordance with safety, health, environment, financial, and quality requirements, assist in producing a civil and structural progress report for approval submissions and assist in preparing progress claims based on construction work variations. One element from CLO of On Job Training is selected to be in this soft skill. The element is applied knowledge and relevant skills in the workplace. Another element from NOSS Level 3 sub-sector construction site supervisor participates in technical meetings. These five elements should be in ethics and professional morals because the first level in this soft skill is the ability to understand economic, environmental and socioeconomic effects in professional practice (Ministry of Higher Education, 2006).

For the fourth soft skills which are leadership skills, there are five elements selected to be in these soft skills. Three elements from NOSS Level 3 sub-sector construction site supervisor which are supervised personnel performance, attend to personal welfare and supervise personnel discipline. The other two elements are from CLO of Diploma in Construction Technology. The elements assist in the administration of construction project management and assist in personnel management at a construction site. These elements should be in leadership skill because the ability to lead a project is the second level in leadership skill (Ministry of Higher Education, 2006).

Application of soft skills in the curriculum is implemented to fulfil industry requirement that needs a knowledgeable and honourable worker to face the challenges of economic globalisation industry (Curriculum Development Centre, 1999). Students who master soft skills will be flexible, dynamic, honourable and skilful in completing tasks (Radzi \& Udin, 2011). Soft skills that are acquired in the education such as problem-solving skill, critical thinking skills, effective communication, and teamwork do not replace the discipline specific skills. As a matter of fact, it makes students gain technical skill and professional knowledge (Hassan et. al., 2007). For example, easier to accept learning in groups and solving a problem. At the same time, students will gain knowledge that they have learned (Melvyn Dodrigh, 1999).

Soft skill is important to a worker in order to turn Malaysia into a competitive industrial country (Hassan et.al., 2007). Nowadays, most employers need workers who possess not only technical skills but also soft skills to increase company's productivity as well as competitiveness. A person who acquires soft skills will adapt to any sort of jobs and becomes versatile (Hassan et.al., 2007). The soft skills that have been pointed out by Ministry of Education is in line with building construction industry that requires skills in collecting, analysing and managing information, communication, planning and organising activities, teamwork, using ideas and techniques in mathematics, problem solving, using technology and understanding culture (Paul Hagel et. al., 2001).

In total, there are 21 elements should be considered to be soft skills elements in the industry' On Job Training assessment rubric. Six elements in communication skill, five elements in critical thinking and problem-solving skill, five elements in ethics and professional morals and five elements in leadership skill 


\subsection{Discarded Elements in Course Learning Outcome of On Job Training (OJT) and Course Learning Outcome of Diploma in Construction Technology}

Two elements from CLO of OJT should be discarded. The elements are applied problem-solving skills, critical thinking, and scientific approach and discover professional development and engage in lifelong learning. The result from the expert validation shows that these two elements were too general in describing the task that leads to a problem in measuring the outcomes.

While 30 elements from CLO of Diploma in Construction Technology should be discarded. According to the experts, there are a few reasons that cause these 30 elements not appropriate to be the constructs and elements for OJT assessment rubric (Organisation). Some of the reasons are:

- Difficulties in finding the measurement technique according to the verb used in the CLO.

- The task is not appropriate to be completed during OJT because of time constraint.

- The task stated is not a job scope of a site supervisor

- Execution of task depends on the company's decision such as build community project.

- The task is at management level

- Not enough knowledge and inexperience to perform the task

- No capacity to perform the task as the specifications have been done by architect and engineer.

\section{Conclusion}

A good assessment rubric should have sufficient criteria in assessing students' performance in On Job Training. It will help in producing competent graduates that possess high potential in becoming skilled workers in the future. However, only a little attention has been given to the criteria of industry' On Job Training assessment rubric. The current On Job Training (Organisation) assessment rubric of Diploma in Construction Technology is quite general in assessing students' performance during OJT. Also, the constructs in current assessment rubric for an organisation focused more on soft skills. From the data analysis of this study, there are 110 elements should be considered to be the constructs and elements in industry' On Job Training assessment rubric. 45 elements should be in the technical skill while 21 elements should be in the soft skills. Another five elements should be the constructs of technical skills while four elements should be the constructs for soft skills and remaining elements should be discarded. Thus, further research is suggested to conduct a pilot study for the reliability of constructs and elements of developed On Job Training (Organisation) assessment rubric of Diploma in Construction Technology.

\section{Acknowledgement}

The authors would like to express our heartfelt thanks to Universiti Kebangsaan Malaysia (Pusat Pengurusan Penyelidikan dan Instrumentasi - Geran Galakan Penyelidik Muda) for supporting this research. Credit also goes to various organisations, which facilitated the successful completion of this research.

\section{References}

Ab Rahman, A., Muhamad Hanafi, N., Mukhtar, M. I., \& Ahmad, J. (2014). Assessment Practices for Competency Based Education and Training in Vocational College, Malaysia: International Conference on Education \& Educational Psychology 2013 (ICEEPSY 2013) (1070-1076). Antalya, Turki: Elsevier.

Australian Skills Quality Authority. (2013). Report: Training for the White Card for Australia's Construction Industry. Melbourne: Australian Skills Quality Authority.

Aziz, A. A. (2011). Rasch Model Fundamentals: Scale Construct and Measurement Structure. Kuala Lumpur: Integrated Advance Planning Sdn Bhd.

Buletin Anjakan. (2015, September). Transformasi Pendidikan Vokasional. Retrieved from http://www.padu.edu.my/files/Buletin_Anjakan_Bil_8_18112015.pdf

Burns, R. B. (2000). Introduction to Research Methods. London, UK: SAGE

Chinyemba, F., Bvekerwa, S. T., Chirimuta, C., Sithole, L., \& Gwangwava, E. (2012). Assessment of Industrial Attachment: Issues and Concers of Chinhoyi University of Technology's Undergraduate Degree Programme, Zimbabwe. US-China Education Review, B 12. 985-996.

Clayton, C.R.I, \& Uff, J. F. F. (1986). Recommendations for the procurement of ground investigation. London: Construction Industry Research and Information Association.

Curriculum Development Centre. (2001). Generic Skills. Kuala Lumpur: Ministry of Education. 
De Luca, C., \& Bolden, B. (2014). Music Performance Assessment Exploring Three Approaches for Quality Rubric Construction. Music Educators Journal. 70-76.

Department of Technical Education and Vocational. (2017). Vocational College Standard Curriculum. Putrajaya: Ministry of Education.

Department of Skills Development. (2016). National Occupational Skills Standard (NOSS) Registry. Cyberjaya, Selangor: Jabatan Pembangunan Kemahiran, Kementerian Sumber Manusia, Malaysia.

EngineeringCivil.org. (2016). Civil Engineering. Retrieved from https://engineeringcivil.org/articles/civil-engineering/

Green, K. E. \& Frantom, C. G. (2002). Survey Development and Validation with Rasch Model: International Conference on Questionnaire Development, Evaluation and Testing. Charleston, SC.

Gronlund, N.E. (1998). Assessment of Student Achievement (6th ed.).

Hassan, Z.; Rahman, M. A. B. A.; Ghafar, M. N. B. A.; Zakaria, K.2007. Penerapan Kemahiran Generik dalam Pengajaran Kejuruteraan di Sekolah Menengah Teknik di Terengganu: Seminar Maktab Perguruan Batu Lintang. Kuching, Sarawak

IACBE. (2014, September). Bloom's Taxonomy of Educational Objectives and Writing Intended Learning Outcomes Statements. Retrieved from http://iacbe.org/pdf/blooms-taxonomy.pdf

Makhtar, M. A. (2015). Kajian Motivasi Terhadap Pelajar Kolej Vokasional Dalam Melaksanakan Kerja-Kerja Kemahiran Teknikal. Universiti Tun Hussein Onn Malaysia, Malaysia.

Manitoba Education, Citizenship and Youth. (2004). Senior 1 to Senior 4 Spanish Language and Culture A Foundation for Implementation. Manitoba: Manitoba Education, Citizenship and Youth.

Melvyn Dodridge. (1999). Generic Skill Requirement for Engineer in the $21^{\text {st }}$ Century. United Kingdom: School of Engineering University of Derby

Ministry of Education. (2014). Garis Panduan On Job Training (OJT). Putrajaya: Bahagian Pendidikan Teknik dan Vokasional, Kementerian Pendidikan Malaysia.

Ministry of Education. (2016). Garis Panduan On Job Training (OJT). Putrajaya: Bahagian Pendidikan Teknik dan Vokasional, Kementerian Pendidikan Malaysia.

Ministry of Higher Education. (2006). Modul Pembangunan Kemahiran Insaniah (Soft Skills) Untuk Institusi Pengajian Tinggi Malaysia. Serdang: Penerbit Universiti Putra Malaysia.

Najmi, H. S. (2011). Project Management for Construction Projects. Master Thesis. Palestine: An-Najah National University.

Paul Hagel, Suzanne Crowley and John Carrick. (2001). Soft Skills in the Construction Industry: How can the generic competencies assist continuous improvement. Sydney: University of Technology.

Parke, C. S. (2001). An approach that examines sources of misfit to improve performance assessment items and rubrics. Educational Assessment, 7, 3. 201-205

Rapley, T. (2007). Doing Conversations Discourse and Document Analysis. London: Sage Publications Ltd.

Radzi, M. S. M., \& Udin, R. H. A. (2011). Menyelesaikan Masalah Pembangunan Akhlak Pelajar: Analisis Penerapan Kemahiran Generik Dalam Amalan Pendidikan. Journal of Edupres, 1. 223-229

Reddy, M. Y. Design and development of rubrics to improve assessment outcomes: A pilot study in a Master's level business programme in India. Quality Assurance in Education, 19, 1. 84-104

The Institution of Professional Engineers New Zealand Incorporated. (2009). Structural Engineering Design Office Practice. New Zealand: IPENZ Engineers New Zealand.

Wood, H. L., \& Ashton, P. (2007). An Investigation to Identify the Role of Pre-Construction Site Investigative Information Used by Small Medium Sized Enterprises (SME). Procs 23rd Annual ARCOM Conference (703-712). UK: Association of Researchers in Construction Management 